\title{
Tree Species Diversity and Population Structure in the Tropical Forests of North Central Eastern Ghats, India
}

\author{
Dumpa PREMAVANI, Maradana TARAKESWARA NAIDU*, \\ Malleboyina VENKAIAH
}

Department of Botany, Andhra University, Visakhapatnam, India; premavani.d@gmail.com, tarakeswaranaidu@gmail.com ("correspondingauthor), venkaiah_botany@rediffmail.com

\begin{abstract}
The tree species diversity and population structure were studied in four stands of the tropical forests in the north-central Eastern Ghats, based on tree inventories conducted on four 1-ha plots. In the four independent plots, two 5 x $1000 \mathrm{~m}$ transects were established and all trees with $\geq 15 \mathrm{~cm}$ girth at breast height were enumerated. The density, frequency, basal area and IVI along with diversity indices viz. Shannon index, species richness, equitability and species dominance were computed to see the variation in tree community. A total of 92 species representing 73 genera under 40 families of angiosperms were recorded. Tree species richness was as low as 34 species per hectare plot in Geddapalli to as high as 48 species in Koruturu. Tree density ranged from 360 stems per hectare in plot Geddapalli to 526 stems in plot Chintapalli and that of total basal area from $16.31 \mathrm{~m}^{2} \mathrm{ha}^{-1}$ in Koruturu to $31.15 \mathrm{~m}^{2} \mathrm{ha}^{-1}$ in Chintapalli. The number of species and stems decreased from the smaller to the largest girth classes. The tree inventories of the study area when compared to those of the other tropical forests showed great differences in density and basal area. This may probably be due to differences in geography and annual rainfall patterns. The information on tree species structure and function can provide baseline information for conservation of the biodiversity.
\end{abstract}

Keywords: diversity index, dominance, girth class, population structure, tree basal area

\section{Introduction}

Tropical forests are the most complex of all the terrestrial ecosystems. They provide many goods and ecosystem services, such as prevention of soil erosion and preservation of habitats for plants and animals (Anbarashan and Parthasarathy, 2013). Although tropical forests occupy only $7 \%$ of the earth's land surface (Wilson, 1988), they harbors about two thirds of all biological populations (Hughes et al., 1997). Phytogeographically, these forests are characterized by a large biological diversity and enriched with economically important species (Hare et al., 1997). On a global basis, $52 \%$ of total forests are tropical and over $42 \%$ of tropical forests have been classified as dry forests (Holdridge, 1967) and these currently are disappearing at an alarming rate, ranging between $0.8-2 \%$ per year (May and Stumpf, 2000; Sagar et al., 2003). Many tropical forests are under great anthropogenic pressure and require management interventions to maintain the overall biodiversity, productivity and sustainability (Kumar et al., 2006). Trees from the major structural and functional basis of tropical forest ecosystems can serve as robust indicators of changes and stresses at the landscape scale (Sahu et al., $2012 \mathrm{~b}$ ). Plant diversity inventories in tropical forests have mostly been concentrated on tree species than other life forms, because tree species diversity is an important aspect of forest ecosystem diversity and also fundamental to total tropical forest biodiversity (Rennols and Laumonier, 2000). They provide resources and habitat structure for almost all other species and form the major biotic component in the forest ecosystem.

Eastern Ghats are a long chain of broken hills and elevated plateaus, running along the east coast of India in the states of Orissa, Andhra Pradesh, Tamil Nadu and Karnataka. The topography and varied climate promoted luxurious growth of plants and diverse forests with a number of invaluable medicinal plant species (Rawat, 1997; Sahu et al., 2012a). Certain wild crop relatives have been reported from these tracts, giving these landscapes special conservation value as sources of novel genes for future crops. This rich biodiversity is being utilized by the inhabitants of the region for medicine, food (wild edible), fodder, fuel, timber, making agricultural tools, religious and other purposes. As the Eastern Ghats constitute important catchments of the peninsula and natural resource, they are 
threatened due to anthropogenic disturbances, such as indiscriminate collection of fodder, fuel species, extraction of timber and minerals from the forests besides the shifting cultivation (Reddy et al., 2008). Several authors have studied the flora and stressed the need for better conservation of the Eastern Ghats.

In peninsular India, quantitative phytodiversity related inventories from the forests of Eastern Ghats are very few. Some studies related to Eastern Ghats of Tamil Nadu (Kadavul and Parthasarathy, 1999a, b; Jayakumar et al., 2002; Natarajan et al., 2004; Pitchairamu et al., 2008; Pragasan and Parthasarathy, 2010); Orissa (Reddy et al., 2007; Sahu et al., 2012a, b; Sahu et al., 2007; Dash et al., 2009), Andhra Pradesh (Rawat, 1997; Reddy et al., 2008; Reddy and Ugle, 2008; Rao et al., 2011) are available. Such studies about Eastern Ghats are very few in the state of Andhra Pradesh, though it has major tracts of Eastern Ghats. Therefore, the present study was conceived to compare the species diversity, density and stand structure of the four plots of north-central Eastern Ghats, in the West Godavari district of Andhra Pradesh.

\section{Material and methods}

\section{Study area}

The study was carried out in four forest stands in the tropical dry deciduous forests (Champion and Seth, 1968) located in West Godavari district, Andhra Pradesh and the plots are $330 \mathrm{~km}$ south- west of Visakhapatnam city. They include Chintapalli (CP), Puliramudugudem (PG), Koruturu (KT) and Geddapalli (GP). The West Godavari district is located between the northern latitudes of $16^{\circ}-15^{\prime}$ and $17^{\circ}-30^{\prime}$ and eastern longitudes of $80^{\circ}-50^{\prime}$ and $81^{\circ}-55^{\prime}$ bound on the north by Khammam district, on the south by Bay of Bengal and a small part of Krishna district, on the east by the river Godavari and on the west by Krishna district. The elevation measures about $450 \mathrm{~m}$ above the mean sea level. Geological formation of the region consists in chiefly crystalline metamorphic rocks. Soil of north central Eastern Ghats is loamy, black, lateritic and alluvial. Lateritic soils are the common type along the deciduous forests in the area. There are three distinct seasons in a year: winter (November to February), summer (March to June) and rainy season (July to October). The maximum temperature ranges between $28.0-46.2^{\circ} \mathrm{C}$ and minimum temperature ranges between $12.9-27.0^{\circ} \mathrm{C}$. The maximum rainfall is $1300 \mathrm{~mm}$ per annum during south-west monsoon period. Similar pattern of temperature and rainfall prevails throughout the year for all the four studied plots. The relative humidity varied between $70-88 \%$.

\section{Field methods}

For determination of biodiversity, the methodology prescribed by the National Bioresource Development Board, Department of Biotechnology, Government of India was followed. In all the four study plots, two belts transects of size $5 \times 1000 \mathrm{~m}$ (totaling $1 \mathrm{ha}$ ) were randomly laid during the calendar years $2007-2009$ and all live trees with $\geq 15$ $\mathrm{cm}$ girth at breast height (gbh) were enumerated. The height of trees was measured using a clinometer. Depending on the shape of the forest stand, these transects were subdivided into fifty $5 \times 20 \mathrm{~m}$ quadrats. The representative taxa were collected and identified with the help of regional floras (Gamble and Fischer, 1915-1935; Rao et al., 1986) and preserved into herbarium. The voucher specimens were deposited in the Botany Department Herbarium (BDH), Department of Botany, Andhra University, Visakhapatnam.

\section{Data analysis}

Based on the individuals recorded in the discrete plot samples, vegetation data were quantitatively analysed for basal area, relative density, relative frequency and relative dominance.

The importance value index of tree species was determined as the sum of relative frequency, relative density and relative dominance (Curtis and McIntosh, 1950).

The data collected were also used to compute community indices like species diversity $\left(\mathrm{H}^{\prime}\right)$ of different tree species; it was calculated using the Shannon- Weiner Index (Shannon and Weiner, 1963):

$$
\mathrm{H}^{\prime}=-\Sigma(\mathrm{ni} / \mathrm{N}) / \mathrm{n}(\mathrm{ni} / \mathrm{N}),
$$

where, $\mathrm{Pi}=\mathrm{ni} / \mathrm{N}$, which denotes the importance probability of each species in a population, $\mathrm{ni}=$ importance of value of species and $\mathrm{N}$ is the total number of individuals of all species in that vegetation type.

Species dominance (Cd) was calculated following Simpson (Simpson, 1949):

$$
\mathrm{Cd}=\Sigma(\mathrm{ni} / \mathrm{N})^{2},
$$

where, ni and $\mathrm{N}$ are the same as those for ShannonWeiner information function.

Equitability of evenness refers to the degree of relative dominance of each species in that area. It was calculated according to Pielou (1966) as:

$$
\text { Evenness }(\mathrm{e})=\mathrm{H}^{\prime} / \log \mathrm{S}
$$

where, $H^{\prime}=$ Shannon index, $S=$ number of species.

Species richness was determined by Margalef index (1968) as:

$$
\mathrm{d}=\mathrm{S}_{1} / \log \mathrm{N}
$$

where, $S$ is the number of species and $\mathrm{N}$ is the number of individuals.

Structural composition was analysed by comparing the distribution of tree height and diameter classes.

\section{Results}

\section{Floristic composition and species richness}

A total of 1789 stems with $\geq 15 \mathrm{~cm}$ gbh were recorded within four 1 ha plots, representing 92 species belonging to 73 genera under 40 families. Of these, 27 families comprise 41 genera, 46 species and 526 individuals were recorded in plot CP; 28 families contributing 43 genera, 46 species and 447 individuals represented in plot PG, whereas 25 families comprising 41 genera, 48 species and 456 individuals reported in plot KT and 21 families represented 30 genera, 34 species with 360 individuals in plot GP (Tab. 1). With 
450

regard to the number of species found within families, Papilionaceae and Mimosaceae were the most diverse families in the samples, each being represented by seven species; they were followed by Rubiaceae (6 species), Combretaceae and Euphorbiaceae (5 species each), Annonaceae, Moraceae, Rutaceae and Verbenaceae (4 species each), Apocynaceae, Caesalpiniaceae, Ebenaceae, Meliaceae (3 species each), Anacardiaceae, Bignoniaceae, Bombacaceae, Burseraceae, Loganiaceae, Sapindaceae and Ulmaceae (2 species each) and 19 families were represented only by single species.

Tab. 1. Number of taxa, diversity indices and structural characteristics of four 1-ha plots in the North-central Eastern Ghats

\begin{tabular}{ccccc}
\hline Variables & CP & PG & KT & GP \\
\hline Number of species & 46 & 46 & 48 & 34 \\
\hline Number of genera & 41 & 43 & 41 & 30 \\
\hline Number of families & 27 & 28 & 25 & 21 \\
\hline Density & 526 & 447 & 456 & 360 \\
\hline Basal area m ha $^{-1}$ & 31.16 & 23.36 & 16.32 & 17.04 \\
\hline Shannon_H & 3.55 & 3.47 & 3.48 & 3.32 \\
\hline Simpson_1-D & 0.96 & 0.97 & 0.95 & 0.96 \\
\hline Evenness_e & 0.76 & 0.71 & 0.68 & 0.81 \\
\hline Margalef & 7.18 & 7.37 & 7.68 & 5.61 \\
\hline Elevation & 316 & 185 & 88 & 334 \\
\hline Latitude & $17^{\circ} 19^{\prime} 446^{\prime \prime}$ & $17^{\circ} 15^{\prime} 181^{\prime \prime}$ & $17^{\circ} 26^{\prime}$ & $17^{\circ} 20^{\prime}$ \\
\hline Longitude & $81^{\circ} 28^{\prime} 293^{\prime \prime}$ & $81^{\circ} 25^{\prime} 875^{\prime \prime}$ & $81^{\circ} 32^{\prime}$ & $81^{\circ} 28^{\prime}$ \\
& & & $081^{\prime \prime}$ & $836^{\prime \prime}$ \\
\hline
\end{tabular}

The mean tree density is 447 stems for 1 ha and density ranges from $360-526$ stem ha $^{-1}$. The stand density is more for plot $\mathrm{CP}$ and less for plot GP. Basal area ranged between $16.32 \mathrm{~m}^{2} \mathrm{ha}^{-1}-31.16 \mathrm{~m}^{2} \mathrm{ha}^{-1}$ and mean basal area was $22 \mathrm{~m}^{2}$ $\mathrm{ha}^{-1}$. Basal area is more voluminous in plot CP and less voluminous in plot GP.

Tree girth class-wise density is more for $31-60 \mathrm{~cm}$ gbh class interval, with $32.9 \%$, while the class interval $<30 \mathrm{~cm}$ accounted for $20 \%$, girth interval between $91-120 \mathrm{~cm}$ accounted $15.09 \%$ and less abundance is for class interval $>120 \mathrm{~cm}$, with $12.5 \%$. The stand structure based on girth frequency of species has a greater number of trees in lower size class particularly in plot CP and plot KT compared to plot PG and plot GP (Tab. 2). Stem density across girth classes in all the study plots decreased from the smallest to the largest trees, except in first girth class ( $<30$ girth class). Tree girth class-wise basal area is more for $>120 \mathrm{~cm}$ class represents $51 \mathrm{~m}^{2} \mathrm{ha}^{-1}$ and less for $<30 \mathrm{~cm}$ girth intervals with $1.64 \% \mathrm{~m}^{2} \mathrm{ha}^{-1}$.

The mean tree height is $18.5 \mathrm{~m}$ with the high ranging between $2-20 \mathrm{~m}$. Tree distribution by height intervals shows that around $22 \%$ of individuals are in $<5 \mathrm{~m}$, about $60 \%$ of individuals fall in 5-10 m height interval and only $14 \%$ of individuals are contributed by $11-15 \mathrm{~m}$ interval, while $>15$ $\mathrm{m}$ tree species are very few and constitute about $2.9 \%$ of total individuals (Tab. 3).

\section{Importance value index (IVI) and diversity}

The IVI values of the 92 species varied considerably (Tab. 4). The IVI of the top ten tree species contributed by $76.5 \%, 48 \%, 44.4 \%$ and $51.7 \%$ of total IVI values respectively for plots CP, PG, KT and GP. Cleistanthus collinus is the dominant species in plot CP (IVI 105.34) accounting for $35.1 \%$ of total IVI. The co-dominant species is Dalbergia paniculalta (IVI 17.26) accounting for 5.7\% of total IVI. The other species with IVI values greater than 10 include Xylia xylocarpa, Terminalia alata, Ficus religiosa, Schleichera oleosa, Grewia tiliaefolia, Ficus benghalensis and Terminalia bellirica; these accounted for $3.5-5.6 \%$ of total IVI.

Tab. 2. Girth class-wise population density of tree species $(\geq 15 \mathrm{~cm}$ gbh) in four 1-ha plots

\begin{tabular}{|c|c|c|c|c|c|c|}
\hline \multirow{2}{*}{$\begin{array}{l}\text { Gbh m }{ }^{2} \\
\mathrm{ha}^{-1}(\mathrm{~cm})\end{array}$} & \multicolumn{4}{|c|}{ Plot } & \multirow{2}{*}{ Individuals } & \multirow{2}{*}{$\%$ of Individuals } \\
\hline & $\mathrm{CP}$ & PG & KT & GP & & \\
\hline$<30$ & 112 & 94 & 92 & 59 & 357 & 19.95 \\
\hline $31-60$ & 167 & 134 & 180 & 109 & 590 & 32.97 \\
\hline $61-90$ & 87 & 92 & 72 & 97 & 348 & 19.45 \\
\hline $91-120$ & 65 & 71 & 68 & 66 & 270 & 15.09 \\
\hline$>120$ & 95 & 56 & 44 & 29 & 224 & 12.52 \\
\hline Total & 526 & 447 & 456 & 360 & 1789 & 100 \\
\hline
\end{tabular}

Tab. 3. Height class-wise proportion of tree individuals in four 1-ha plots

\begin{tabular}{|c|c|c|c|c|c|c|}
\hline \multirow{2}{*}{ Height } & \multicolumn{4}{|c|}{ Plot } & \multirow{2}{*}{ Individuals } & \multirow{2}{*}{$\begin{array}{c}\% \text { of } \\
\text { Individuals }\end{array}$} \\
\hline & CP & PG & KT & GP & & \\
\hline$\leq 5 \mathrm{~m}$ & 126 & 106 & 107 & 59 & 398 & 22.24 \\
\hline $6-10 \mathrm{~m}$ & 308 & 246 & 289 & 238 & 1081 & 60.42 \\
\hline $11-15 \mathrm{~m}$ & 71 & 78 & 49 & 59 & 257 & 14.36 \\
\hline$>15 \mathrm{~m}$ & 21 & 17 & 11 & 4 & 53 & 2.96 \\
\hline Total & 526 & 447 & 456 & 360 & 1789 & 100 \\
\hline
\end{tabular}

In plot PG, Dalbergia paniculata was the dominant species (IVI 24.15) which contributed with $8 \%$ of total IVI. Tamarindus indica was the co-domonant species (IVI 20.11) accounting for $6.7 \%$ of total IVI. The other species with IVI greater than 10 include Haldinia cordifolia, Anogeissus acuinata, Terminalia alata, Chloroxylon swietenia, Lannea coromandelica and Strychnos nux-vomica, which accounted for $4-6 \%$ of the total IVI.

In the plot KT, Cleistanthus collinus, Dalbergia paniculata, Terminalia alata, Schleichera oleosa, Anogeissus latifolia and Albizia odoratissima had IVI values greater than 10. Cleistanthus collinus had the largest IVI, with a value of 21.52 , accounting for $7.1 \%$ of total IVI, followed by Dalbergia paniculata with IVI - 18.9 accounting for $6.3 \%$ of the total IVI. The IVI of the other four species ranged between 10.67-17.21, accounting for 3.5 - 5.7\% of total IVI.

In the plot GP, species with IVI greater than 10 include Anogeissus latifolia, Xylia xylocarpa, Ficus religiosa, Bombax ceiba, Anogeissus acuminata, Terminalia alata, Albizia odoratissima, Lannea coromandelica, Alangium salvifolium and Albizia lebeck accounted for above $50 \%$ of total IVI. Anogeissus latifolia is the dominant species with 19.11 IVI, accounted for $6.3 \%$ of the total IVI. Xylia xylocarpa is the co-dominant with $18.11 \mathrm{IVI}$, accounted for $6 \%$ of the total IVI.

Diversity of tree species in the study plots calculated using the Shannon-Weiner diversity index $\left(\mathrm{H}^{\prime}\right)$ showed values of $3.55,3.47,3.48$ and 3.32 for the plots of $\mathrm{CP}$, PG, KT and GP respectively. The values for Simpson's index were $0.96,0.97,0.95$ and 0.96 for the plots of CP, PG, KT and GP respectively. Pielou's evenness index of tree communities at $\mathrm{CP}, \mathrm{PG}, \mathrm{KT}$ and GP plots showed values of $0.76,0.71,0.68$ and 0.81 respectively. The Margalef species 
Tab. 4. Top ten IVI of the tree species in four 1-ha plots

\begin{tabular}{|c|c|c|c|c|}
\hline Species & $\mathrm{CP}$ & PG & KT & GP \\
\hline Alangium salvifolium & - & - & - & 11.32 \\
\hline Albizia lebeck & - & - & - & 10.73 \\
\hline Albizia odoratissima & - & - & 10.67 & 14.16 \\
\hline Anogeissus acuminata & - & 15.66 & 12.8 & 16.81 \\
\hline Anogeissus latifolia & - & - & - & 19.11 \\
\hline Bombaxceiba & 9.92 & - & 9.58 & 17.8 \\
\hline Chloroxylon swietenia & - & 13.98 & & - \\
\hline Cleistanthus collinus & $105.34^{*}$ & - & $21.52^{*}$ & - \\
\hline Dalbergia paniculata & 17.26 & $24.15^{*}$ & 18.99 & - \\
\hline Ficus benghalensis & 10.88 & - & - & - \\
\hline Ficus religiosa & 16.26 & 13.98 & - & 17.85 \\
\hline Grewia tiliaefolia & 12.16 & - & - & - \\
\hline Haldinia cordifolia & - & 17.94 & 9.45 & - \\
\hline Lannea coromandelica & - & 11.81 & 9.89 & 12.7 \\
\hline Polyalthia cearsoides & - & 8.04 & - & - \\
\hline Sapindus emarginatus & - & 7.56 & - & - \\
\hline Schleichera oleosa & 13.00 & - & 13.84 & - \\
\hline Semecarpus anacardium & - & - & 9.29 & - \\
\hline Strychnos nux-vomica & - & 10.78 & - & - \\
\hline Tamarindus indica & - & 20.11 & - & - \\
\hline Terminalia alata & 16.78 & - & 17.21 & 16.72 \\
\hline Terminalia bellirica & 10.73 & - & - & - \\
\hline Xylia xylocarpa & 17.04 & - & - & $18.11^{*}$ \\
\hline Subtotal (10 species) & 229.37 & 144.01 & 133.24 & 155.31 \\
\hline Remaining species & 70.63 & 155.99 & 166.76 & 144.69 \\
\hline Grand total & 300 & 300 & 300 & 300 \\
\hline
\end{tabular}

richness index is 7.18, 7.37,7.68 and 5.61 for plots of CP, PG, KT and GP respectively (Tab. 1).

\section{Discussion}

The tree species richness varied among the four plots. There are 92 species enumerated in the 4 ha of the north central Eastern Ghats. Species richness ranges between 3448 stems ha ${ }^{-1}$. Species richness is higher for plot CP, with 48 species, while GP has least diversity, with 34 species. These study plots are compared with that of tropical dry deciduous forests of Eastern Ghats, southern Andhra Pradesh, which represents 18 - 86 tree species in 3 ha (Reddy et al., 2008), Niyamgiri hill ranges of Orissa with 22-29 species in 0.6 ha (Sahu et al., 2012b), Similipal Biosphere Reserve harbouring 76-121 species in 8.48 ha (Reddy et al., 2007), Khokham Wildlife Sanctuary comprising 11-17 tree species in 2 ha (Pant and Samant, 2012), inland forests and coastal forests of peninsular India with 19-35 and 21-28 tree species respectively in 5 ha each (Mani and Parthasarathy, 2006), tropical dry evergreen forests of Coromandel coast of India harbouring 18-27 species in 4 ha (Anbarashan and Parthasarathy, 2013), tropical dry deciduous forests of western India contributed 18-37 species in 3 ha (Kumar et al., 2010), Kaan forests in the central Westrn Ghats harbouring 28-53 species in 3 ha (Ganuga et al., 2013).

The present study enumerated the presence of 1789 individuals in $4 \mathrm{ha}^{-1}$ study plots. These results were compared with tropical dry deciduous forests of Eastern Ghats, Southern Andhra Pradesh (1541- 3 ha $^{-1}$ - Reddy et al., 2008), Similipal Biosphere Reserve (4819- $8.48 \mathrm{ha}^{-1}$ Reddy et al., 2007), Kaan forests of central Western Ghats (1925- 3 ha $^{-1}$ - Ganuga et al., 2013), Boudh district of Orissa (2364- $4 \mathrm{ha}^{-1}-$ Sahu et al., 2007), Malayagiri hill ranges of Eastern Ghats (1063- 2 ha $^{-1}-$ Sahu et al., 2012a), Inland and coastal dry evergreen forests (4676- $10 \mathrm{ha}^{-1}-$ Mani and Parthasarathy, 2006), tropical dry deciduous forests of Western India (1724- $3 \mathrm{ha}^{-1}-$ Kumar et al., 2010), reserved forests of southern Eastern Ghasts of Andhra Pradesh (3078- 5 ha $^{-1}$ - Rao et al., 2011), tropical dry evergreen forests of Coromandel coast of India (4345- $4 \mathrm{ha}^{-1}$ - Anbarashan and Parthasarathy, 2013).

Girth class-wise frequency population structure of trees in four study plots are in conformity with other forest stands in tropical forests such as Shervarayan hills (Kadavul and Parthasarathy, 1999a), Kalarayan hills (Kadavul and Parthasarathy, 1999b), sacred groves of the Jaintia hills (Upadhaya et al., 2003), Malayagiri hill ranges of Eastern Ghats (Sahu et al., 2012a) and Cerros de Amotape Cordillera, Peru (Palomino and Alvarez, 2005). Species richness and density decreased with the increasing tree size classes in all four plots, as the middle class stems $61-90 \mathrm{~cm}$ contributed with $33 \%$ of total density, whereas the largest size $>120 \mathrm{~cm}$ comprised $12.5 \%$. The trend of decreasing diversity with increasing girth class is similar to that observed by Paijmans (1970) in New Guinea.

The basal area is used as one of the important aspects for studying the forest vegetation structure in most of the studies (Mani and Parthasarathy, 2006). The mean basal area obtained in the present study is $22 \mathrm{~m}^{2} \mathrm{ha}^{1}$, as it ranges between $16.32-31.16 \mathrm{~m}^{2} \mathrm{ha}^{-1}$; with this value, is greater than the one for tropical forests of Hainan Island, with 17.04$21.11 \mathrm{~m}^{2} \mathrm{ha}^{-1}$ (Meng et al., 2011), Niyamgiri hill range of Eastern Ghats constituted 3.16- $10.04 \mathrm{~m}^{2} \mathrm{ha}^{-1}$ (Sahu et al., 2012a), Cerros de Amotape Cordillera, Peru comprised 2.31- $22.79 \mathrm{~m}^{2} \mathrm{ha}^{-1}$ (Palomino and Alvarez, 2005), tropical forests of southern Eastern Ghats harboring 5.6- $24.4 \mathrm{~m}^{2}$ ha ${ }^{1}$ (Pragasan and Parthasarathy, 2010). This value is closer of near reserved forests of southern Eastern Ghats of Andhra Pradesh has 10.5- 31.7 (Rao et al., 2011), tropical dry deciduous forests of Eastern Ghats, Southern Andhra 
452

Pradesh with 8.55- $34.39 \mathrm{~m}^{2}$ ha $^{-1}$ (Reddy et al., 2008), but lower than that of 61.32- $70.93 \mathrm{~m}^{2}$ ha' ${ }^{-1}$ for Niyamgiri hill ranges of Orissa (Dash et al., 2009), sacred groves of Jaintia hills contributed 57.46- $77.44 \mathrm{~m}^{2} \mathrm{ha}^{-1}$ (Upadhaya et al., 2003), fan-palm dominated forests of east coast peninsular Malaysia with 25.3- $48.6 \mathrm{~m}^{2} \mathrm{ha}^{-1}$ (Nizam et al., 2013). The basal area and vertical structure of a forest is difficult to summarize as these depend heavily upon climate and prevailing edaphic factors.

The Shannon-Weiner varied among all plots is 3.55 , $3.47,3.48$ and 3.32, which are compared with other findings of lowland forests of Cameroon, 3.9-4.12 (Gonmadje et al., 2011), in Niyamgiri hill ranges of Orissa, 3.84- 4.86 (Dash et al., 2009), in tropical dry evergreen forests of Coromandel coast of India, 1.24- 2.4 (Anbarashan and Parthasarathy, 2013), in inland and costal tropical dry evergreen forests, 1.29- 2.44 (Mani and Parthasarathy, 2006), in the tropical semi evergreen forests in the Shervarayan hills, 2.37- 3.072 (Kadavul and Parthasarathy, 1999a), in tropical dry deciduous forests of southern Andhra Pradesh, 4.11- 4.89 (Reddy et al., 2008) and tropical dry deciduous forests of Boudh district of Orissa, 4.51 (Sahu et al., 2007). The evenness index in the present study sites were within the range for tropical forests, between 0.64-1.34 (Lalfakwma $e t$ al., 2009; Sahu et al., 2012a). The dominance index values obtained in the current study ranges between 0.95-0.97, which are close to the value of tropics (Reddy et al., 2007).

\section{Conclusion}

Tropical dry deciduous forests are a critical repository of India's biodiversity and are threatened due to wide spread of habitat destruction. Plant diversity inventories in tropical forests have mostly been concentrated on tree species than other life-forms, because tree species diversity is an important aspect of forest ecosystem diversity and also fundamental for total tropical forest biodiversity. The present quantitative inventory of tree species diversity revealed considerable variation in the composition of dominant species and stand density in various forest areas. The IVI values have helped to understand the ecological significance of the tree species in community structure. The present study clearly established the fact that the tree diversity in tropical forests of Eastern Ghats varied greatly from location to location, mainly due to variation in biogeography and habitat disturbance. Most of the species present in these communities are used for fuel, fodder, making agricultural tools, house building and miscellaneous purposes. During the surveys, it has been observed that use-pressure on species along with heavy grazing is responsible for habitat degradation, poor regeneration and population depletion of the tree species.

\section{Acknowledgements}

The authors are grateful to the Department of Biotechnology, Government of India, for providing financial support. Thanks are due to the officials of the Andhra Pradesh forest department for their help and cooperation.

\section{References}

Anbarashan M, Parthasarathy N (2013). Tree diversity of tropical dry evergreen forests dominated by single or mixed species on the Coromandel Coast of India. Trop Ecol 54(2):179-190.

Champion HG, Seth SK (1968). The revised forest types of India. Government of India, New Delhi p. 404.

Curtis JT, McIntosh RP (1950). The interrelations of certain analytic and synthetic phytosociological characters. Ecology 31:434-455.

Dash PK, Mohapatra PP, Giri Rao Y (2009). Diversity and distribution pattern of tree species in Niyamgiri hill ranges, Orissa, India. Indian For 135:927-942.

Gamble JS, Fischer CEC (1915-1935). Flora of the Presidency of Madras. London. Adlard and son. Vols. I-III.

Ganuga S, Rajeswari N, Vasudeva R (2013). Tree diversity and disturbance of Kaan forests. Relics of a community protected climax vegetation in the central Western Ghats. Trop Ecol 54(1):117-131.

Gonmadje CF, Doumeng C, McKey D, Tchouto GPM, Sunderland TCH, Malinga MPB, Sonke B (2011). Tree diversity and conservation value of Ngovayang's lowland forests, Cameroon. Biodiver Conserv 20(12):2627-2648.

Hare MA, Lantagne DO, Murphy PG, Chero H (1997). Structure and tree species composition in a sub tropical dry forest in Dominican Republic: comparison with a dry forest in Puerto Rico. Trop Ecol 38:1-17.

Holdridge LK (1967). Life zone ecology. San Jose, Coasta Rica, Tropical Science Centre, p. 206.

Hughes JB, Daily GC, Ehrlich PR (1997). Population diversity: its extent and extinction. Science 278:689-692.

Jayakumar S, Arockiasamy DI, Britto SJ (2002). Conserving forests in the Eastern Ghats through remote sensing and GIS. A case study in Kolli hills. Curr Scie 82:1259-1267.

Kadavul K, Parthasarathy N (1999a). Plant biodiversity and conservation of tropical semi-evergreen forest in the Shervarayan hills of Eastern Ghats, India. Biodiver Conserv 8:421-439.

Kadavul K, Parthasarathy N (1999b). Structure and composition of woody species in tropical semi-evergreen forest of Kalrayan hills, Eastern Ghats, India. Trop Ecol 40:247- 260.

Kumar JIN, Kumar RN, Bhoi RK, Sajish PR (2010). Tree species diversity and soil nutrient status in three sites of tropical dry deciduous forest of western India. Trop Ecol 51(2):273-279.

Kumar A, Bruce GM, Ajai S (2006). Tree species diversity and distribution patterns in tropical forests of Garo Hills. Curr Scie 91:1370-1381.

Lalfakwma, Sahoo UK, Roy S, Vanlalhritpuia K, Vanlalhluna PC (2009). Community composition and tree population structure in undisturbed and disturbed tropical semi-evergreen forest stands of North-East India. Appl Ecol Environ Res 7:303-318.

Mani S, Parthasarathy N (2006). Tree diversity and stand structure in inland and Coastal tropical dry evergreen forests of Peninsular India. Curr Scie 90:1238-1246. 
Margalef R (1968). Perspectives in Ecological Theory. University of Chicago Press, Chicago, p. 111.

May RM, Stumpf MPH (2000). Species area relations in tropical forests. Science 290:2084-2086.

Meng J, Lu Y, Lei X, Liu G (2011). Structure and floristics of tropical forests and their implications for restoration of degraded forests of China's Hainan Island. Trop Ecol 52:177-191.

Natarajan D, Britto SJ, Balagaru B, Nagamurugan N, Soosairaj S, Arockiasamy DI (2004). Identification of Conservation priority sites using remote sensing and GIS. A case study from Chitteri hills, Eastern Ghats, Tamil Nadu. Curr Scie 86:1316-1323.

Nizam MS, Jeffri AR, Latiff A (2013). Structure of tree communities and their association with soil properties in two fan-palm dominated forests of east coast Peninsular Malaysia. Trop Ecol 54(2):213-226.

Paijmans K (1970). An analysis of four tropical rain forest sites in New Guinea.J Ecol 58(1):77-101.

Palomino LR, Alvarez SIP (2005). Tree community patterns in seasonally dry tropical forests in the Cerros de Amotape Cordillera, Tumbes, Peru. Fore Ecol Manag 209:261-272.

Pant S, Samant SS (2012). Diversity and regeneration status of tree species in Khokham Wildlife Sanctuary, north-western Himalaya. Trop Ecol 53: 317-331.

Pielou EC (1966). The measurement of diversity in different types of biological collections. J Theo Biol 13:131-144.

Pitchairamu C, Muthuchelian K, Siva N (2008). Floristic inventory and quantitative vegetation analysis of tropical dry deciduous forest in piranmalai forest, Eastern Ghats, Tamil Nadu, India. Ethno Leaf 12:204-216.

Pragasan LA, Parthasarathy N (2010). Landscape-level tree diversity assessment in tropical forests of southern Eastern Ghats, India. Flora 205(11):728-737.

Rao BRP, Babu MVS, Reddy MS, Reddy AM, Rao VS, Sunitha S, Ganeshaiah, KD (2011). Sacred groves in southern Eastern Ghats, India: Are they better managed than forest Reserves. Trop Ecol 52(1):79-90.

Rao RS, Venkanna P, Reddy TA (1986). Flora of West Godavari District, Andhra Pradesh, India. Meerut.

Rawat GS (1997). Conservation status of forests and wildlife in the Eastern Ghats, India. Environ Conser 24:307-315.
Reddy CS, Ugle P (2008). Tree species diversity and distribution patterns in tropical forest of Eastern Ghats, India: a case study. Life Sci Jour 5:1097-8135.

Reddy CS, Babar S, Giriraj A, Reddy KN, Rao T (2008). Structure and floristic composition of tree diversity in tropical dry deciduous forest of Eastern Ghats, southern Andhra Pradesh, India. Asi J Sci Res 1:57-64.

Reddy CS, Pattanaik C, Mohapatra A, Biswal AK (2007). Phytosociological observations on tree diversity of tropical forest of Similipal Biosphere Reserve, Orissa, India. Taiwania 52:352359.

Rennols K, Lamonier Y (2000). Species diversity structure analysis at two sites in the tropical rainforest of Sumatra. J Trop Ecol 116:253-270.

Sagar R, Raghubansi AS, Singh JS (2003). Tree species composition, dispersion and diversity along a disturbance gradient in a dry tropical forest region of India. Fore Ecol Manag 186:61-71.

Sahu SC, Dhal NK, Lal B, Mohanty RC (2012a). Differences in tree species diversity, distribution and population structurein a tropical dry deciduous forest of Malayagiri hill range, Eastern Ghats, India. J Mount Scie 9:492-500.

Sahu SC, Dhal NK, Mohanty RC (2012b). Tree species diversity and soil nutrient status in a tropical sacred forest ecosystem on Niyamgiri hill range, Eastern Ghats, India. Trop Ecol 53:163168.

Sahu SC, Dhal NK, Reddy CS, Pattanaik C, Brahman M (2007). Phytosociological study of tropical dry deciduous forest of Boudh District, Orissa, India. Res J Fore 1:66-72.

Shannon CE, Weiner W (1963). The mathematical theory of communication. University of Illinois Press. Urbana, (U.S.A.), p. 117.

Simpson EH (1949). Measurement of Diversity. Nature 163:688.

Upadhaya K, Pandey HN, Law PS, Tripathi RS (2003). Tree diversity in sacred groves of Jaintia hills in Meghalaya, northeast India. Biodiver Conser 12:583-597.

Wilson EO (1988). The current state of biological diversity. In: Biodiversity ed. Wilson EO, Peter FM, p. 3-18. Washington, DC, USA: National Academy Press. 